\title{
AN OVERVIEW OF COLLAPSE OF BUILDINGS IN NIGERIA: A MEDICO-SPATIAL ANALYSIS
}

\author{
${ }^{1}$ FADAMIRO, Joseph Akinlabi and ${ }^{2}$ ADEDEJI, Joseph Adeniran \\ Department of Architecture, Federal University of Technology, Akure, Nigeria \\ Email: ${ }^{2}$ niranadedeji@yahoo.com
}

\begin{abstract}
The tripartite quality of buildings that qualify as architectural products has been traditionally held to be serviceability, stability and aesthetics. Unfortunately, the Nigerian built environment has lost the stability component of this trio with attendant socio-economic, political and cultural negative outcomes. This is obvious from the reported cases of building collapses in the country. While the literature is replete with numerous studies on the subject matter, the interaction of this spatial problem with medical practice has been grossly neglected. This review paper presents a medico-spatial dimension of building collapse towards understanding its implications on the medical practice, people and places. Through the aid of literature resources, results show multiple interactions among these key variables. The paper enumerates and argues in favour of holistic solutions and asserts that medical professionals should be co-opted as major stakeholders in the formulation, review and enforcement of the National Building Code in Nigeria and elsewhere.
\end{abstract}

Keywords: Architecture, building collapse, medical spaces, professionalism, structures, urban places.

\section{INTRODUCTION}

"A medical doctor, Bukky Coker and her sister, Toyin, a university graduate, including their mother were killed in their sleep on Wednesday in another building collapse in Lagos. They were occupants of Block M20 at the Low Cost Housing Estate, Oke-Afa, Isolo.”(Olabulo, 2012).

The excerpt above demonstrates that building collapse knows no bound in the range of its casualties. It is a monstrous canker and a major component of environmental disaster affecting the whole fabric of Nigerian society. The traumatic pains of its attendant social and economic losses in particular cannot be overemphasized. It is rather thought provoking that "after a few days or weeks of media frenzy attention shifts to other breaking news while for the orphaned and widowed, bereaved and deprived, amputees and disfigured, destitute and broken hearted, the harrowing descent into depression would have just commenced" (Ogunsote and Ogunsote, 2013). The incessant incidences of collapse of buildings in Nigeria has therefore been the concern of numerous authors (Ibrahim, 2013; Adedeji, 2013; Nwachukwu and Emoh, 2011; Oyegbile, Tat and Olutoge, 2012; Akindoyeni, 2012; Akinwale, 2010; Chinwokwu, 2000; etc). The major debates have been causes, consequences, occurrences, and remedies to the problem in Nigeria and globally. This review paper presents a medico-spatial analysis of the problem towards understanding its relevance to the medical practice, people and places. It highlights the symbol- lism of buildings to human body, the case-history, diagnosis, prescription, and prognosis of the future of collapse of buildings in Nigeria.

\section{SICK BUILDING SYNDROME}

In symbolism and semiotic language, buildings have been described as small cities just as cities are big buildings (Aldo Van Eyck, cited by Rapoport, 1979) and are analogous to living organisms (Timmer et al., 2005). According to Leong (2010),

"the city is a living, breathing organism with vital systems and infrastructure that function as a means of sustenance for its inhabitants,......... cities are a cultural reflection of our common humanity in all of its beauty and depravity"

Buildings have a conceptual stage as an idea during design similar to the foetus formation, a developmental stage in construction akin to foetus growth to baby size and a completion stage much similar to the biological birth. Buildings like cities thus have a life and death (Jacobs, 1961) and can be sick. Without biological relevance neither intellectual insult to the infamous Darwinian evolutionism (Jahoda, 2002), Fadamiro and Adedeji (2012) pointed out that,

"primitive settlement transforms into higher human settlement through villages, towns, cities, megacities and hyper-cities..... through the process of settlement development and transformation termed urbanization." 
They argued that as human development is in stages, so is a city and that,

"the morphology of living organisms generally comprising of cell with a nucleus, tissue consisting of cells, organ made up of tissues, system combining a number of organs and the body made up of systems, is instructive to understanding the functioning of city mechanisms."

This psychoanalysis coincides with biologism (Encyclopedia69 Dictionary). However, it should be added that "the biological arguments are used as analogies, in order to show how comparison with biology might throw light on urban life" (Savage and Warde, 1993). Gordon (1961) and de Bono (1977) argued that using terms for the parts of a city based on human and animal anatomy may have value in suggesting ideas for problem solutions through analogy. According to Saunders (2001) "societies function in a similar way to living organisms" and "social arrangements come to reflect natural, biological needs of human organisms."

Carmona et al (2003) identified the component systems of buildings as skeleton (structural frame), spaces (rooms), skin (finishes), surroundings (walls) and services (electrical, mechanical). Before the incidence of the death of a building, it must have been sick or encountered accident. Abnormally sounding doors, fans and air-conditioning systems, pealing finishes, and deformed beams and columns, among many others, are symptomatic evidences of a sick building rooted in too-numerous to mention causal bases. These causal bases may be natural like earthquake or human-made like building malformation in pre-contract stages and post-contract stages. The first collapsed building in history, the Tower of Babel, was due to force majeure (act of God) while the organized international terrorist syndicate attack of September 11, 2001 on the American White House, the pentagon killing many people and destroying the fabrics of many businesses was a genocide of some sort (Golu, 2008). The collapse of the World Trade Centre 110 storeys tower in New York on the same day that lead to innumerable loss of lives was a man-made accident (Adedeji and Adeboyejo, 2011).

\section{BUILDING FAILURES AND STRUCTURAL COLLAPSE}

The centrality of the heart to the continual living and overall functioning of humans is instructive to the understanding the problem of building failures. The structural frame of buildings functions in much similar way to the heart. Made up of beams, columns and floor slabs, it supports the load of the various components of the building and transfers them to the substructure for onward transfer to the subsoil. A failure of this structural system or its equivalent loadbearing structures, like heart failure, is causal to the eventual collapse of a building. Heart-attack that leads to sudden death also explains the sudden collapse of buildings that experiences terrorists' attack or any other kind of accidental collisions like impact loads from aircraft crash.

Thus, building failure is a state when a structure ceases to be fit for human habitation and occurs when the limit state is reached. Technically, this state arises when deflections exceed $\mathrm{L} / 250$, where $\mathrm{L}$ is the span of the element, and crack widths exceed $0.3 \mathrm{~mm}$ (Obiechina, 2005). They create conditions that may not immediately be life threatening but leads to fears, worry, anxiety, doubts and general feelings of unsafe environments by the inhabitants and observers and the structure is considered to have failed.

Further, continual, unabated failure leads to very extreme state of failure and collapse. Thus collapse is "a state of complete failure, when the structure has literally given way and most members has caved-in, crumbled or buckled." This can manifest in three forms in a structure: ultimate limit state, which results in collapse; serviceability limit state, which results in deflections and cracks; and durability, which has to do with deterioration of elements (Obiechina, 2005). These building elements are generally grouped into load-bearing and non-load bearing while the entire structure can be divided into sub-structure, below the finishing of the lowest floor, and super-structure, above the finishing of the lowest floor. These elements can fail and lead to collapse of buildings. It is imperative for medical practitioners to be observant of failure of any of the elements of healthcare buildings and personal buildings and take appropriate actions of warning, evacuation and reporting to the building owner(s) or appropriate authorities.

\section{CASE-HISTORY OF BUILDING COLLAPSE}

In recorded history of the built environment, the Tower of Babel (Fig. 1) whose height was given as 2,484 metres, which is about three times the height of the Burj Khalifa in United Arab Emirates, the tallest building in the world today (Jubilees 10:18-27; Charles, 1913; Wikipedia, 2013b) is the first structure to collapse through the Majestic Power of the Ruler of the Universe and Greatest Architect of all Ages. This was followed by the Wall of Jericho (Joshua 6: 1-27) and the house, filled with the Philistines, where Samson was when he pulled down the two main 
pillars on which the building rested (Judges 16: 2830). This made him to slew more people at his death than in his life (Judges 16: 30).

The global spread of collapse of buildings and the attendant huge loss of human lives in history is implicated upon many forces of interrelationships of natural and human causative agencies. The negative resultant effects of ambitions of humankind in the process of subduing the earth has manifested in collapse of buildings. The major incidences are reported in Table 1 below.

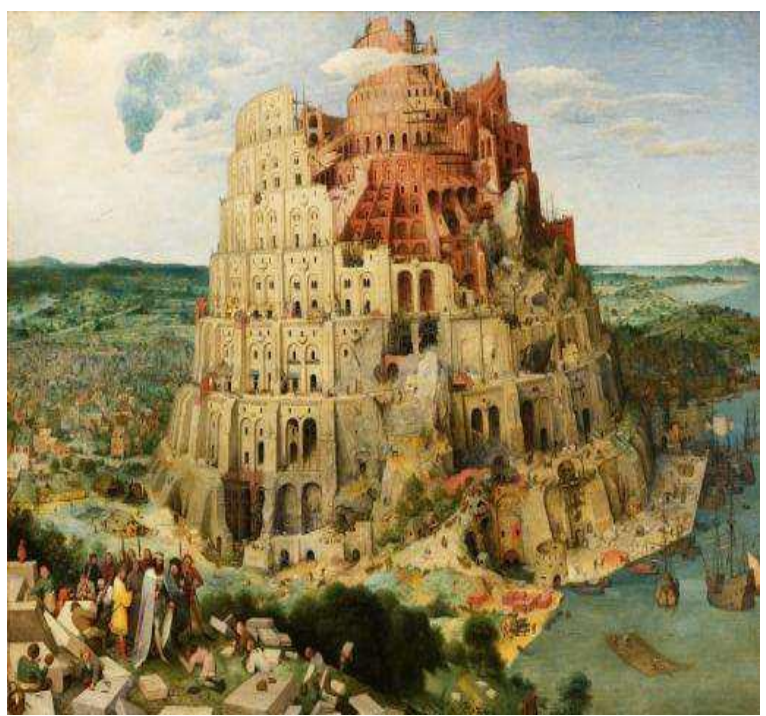

Source: Open History Society (2013), adapted from Ogunsote and Ogunsote, 2013

Figure 1. Artist's impression of the Tower of Babel by Pieter Bruegel the Elder (1563).

\section{INCIDENCES OF BUILDING COLLAPSE IN NIGERIA}

Cities have been described as "crucibles of hazards" (Bull-Kamanga et al, 2003) that generate extreme situations of vulnerability and risk for very large populations. As a negative by-product of urbanisation, incidences of collapse of buildings are rampant in Nigerian urban centres. Between 1974 and 2010, Windapo and Rotimi (2012) documents 91 reported cases of collapse of buildings in many Nigerian cities across all regions with varying causes and scales of loss of lives and properties. Between 2010 and 2013 a quarter hardly passed without the report of collapse of buildings. Table 2 below shows a selected list of reported cases of collapse of buildings in Nigeria.

\section{DIAGNOSIS OF BUILDING COLLAPSE IN NIGERIA}

Buildings malfunction and eventually collapse due to numerous reasons. This is due largely to faulty procedures in the process of building procurement usually evident in quackery of personnel and violation of professional ethics, greed of building contractors, ignorance of building owners, deliberate cornercutting by major stakeholders. Defects may arise during the contract period due to poor design or workmanship particularly when supervision is questionable [37]. Most often, out of sheer ignorance and determination for self-destruction or predetermined destruction of others, the expertise of

Table 1. Major building collapses in history.

\begin{tabular}{|c|c|c|c|}
\hline Date & Structural Collapse & Location & Casualties \\
\hline 27 & Fidenae amphitheatre collapse & $\begin{array}{l}\text { Fidenae, Italia, Roman } \\
\text { Empire }\end{array}$ & More than 20,000. \\
\hline 140 & Upper tier collapse of the Circus Maximus & Rome, Italia, Roman Empire & About 13,000 . \\
\hline 1973 & Skyline Plaza, a 24-storey apartment building & Virginia, USA & 14 killed, 34 injured \\
\hline 1986 & 6-storey Hotel & New World Singapore & 33 killed, 17 injured \\
\hline 1993 & 6-storey Royal Plaza Hotel & $\begin{array}{l}\text { Nakhon Ratchasima, } \\
\text { Thailand }\end{array}$ & 137 killed, 227 injured. \\
\hline 1995 & Sampoong Department Store & Seoul, South Korea & 502 killed, 937 injured \\
\hline 2001 & 110-storey Twin Towers, World Trade Centre & New York, USA & $\begin{array}{l}2,606 \text { killed in the towers and } \\
\text { on the ground }\end{array}$ \\
\hline 2010 & Tenement building & New Delhi, India & 67 killed, 150 injured \\
\hline 2012 & $\begin{array}{l}\text { 20-storey high-rise office building and another 10- } \\
\text { storey and 4- storey building }\end{array}$ & Rio de Janeiro, Brazil & At least 17 killed \\
\hline 2013 & Building under construction & Thane, Mumbai & 45 killed, 50 injured \\
\hline 2013 & Rana Plaza garment factory & Savar, Dhaka, Bangladesh & $\begin{array}{l}\text { More than } 1100 \text { killed, } \\
\text { more than } 2500 \text { injured }\end{array}$ \\
\hline
\end{tabular}

Source: Ogunsote and Ogunsote, 2013; Wikipedia, 2013a, 2013b and Internet search. 
Table 2. Selected Reported Incidences of Collapse of Buildings in Nigeria

\begin{tabular}{|c|c|c|c|}
\hline Date & Type Of Building & Location & Casualties \\
\hline October 1974 & Multi-storey building under construction & Mokola, lbadan & 27 killed. \\
\hline June 1977 & School building & Kaduna & 16 killed, many injured. \\
\hline August 1977 & Housing Estate & Barnawa, Kaduna & 28 killed \\
\hline September 1987 & Residence & Idumota Lagos & 17 killed \\
\hline June 1990 & Sague Comprehensive Pry. and Sec. School & Port Harcourt & 50 killed \\
\hline October 1995 & 3-storey Church Building & Ogba, Lagos & 15 killed \\
\hline June 1997 & 3-storey building under construction & Enugu & 20 killed \\
\hline October 1998 & 4-Storey Church Building & Akure & 8 killed \\
\hline October 1999 & 3-storey Church Building under Constriction & Iju-Isahaja, Lagos & 35 killed \\
\hline October, 1999 & Two Storey Residential Building & Victoria Island, Lagos & 20 killed \\
\hline June 2005 & 4-storey building & Aba & 25 killed, many injured \\
\hline July 2005 & 3-storey building & Lagos & 30 killed, many injured \\
\hline July 2005 & 5-storey office building & Port-Harcourt & 30 killed, many injured \\
\hline July 2006 & 4-storey block of flats & Lagos & 25 killed \\
\hline July 2006 & Block of 36 flats, penthouse and shops & Ebute Metta, Lagos & 57 killed, 50 injured \\
\hline March 2008 & Building used as nursery/primary school & Olomi Area, Ibadan & 13 killed \\
\hline July 2008 & 4-Storey shopping centre under construction & Utako District, Abuja & 70 killed, 30 injured \\
\hline August 2006 & 4-storey building & Lagos & 50 killed, many injured \\
\hline February 2009 & LAUTECH Teaching Hospital Complex & Ogbomoso & 5 killed \\
\hline June 2009 & 2-storey building & Iddo, Lagos & 7 killed, 30 injured \\
\hline August 2010 & 4-storey building & Garki 2, Abuja & 21 killed \\
\hline July 2011 & 3-storey building & Idumota, Lagos & 18 killed \\
\hline
\end{tabular}

Sources: Adedeji (2013); Windapo and Rotimi (2012) Dimuna (2010); Fakere, Fadairo and Fakere (2012); Ike (2012).

architects, engineers and other allied professionals are neglected just as patients are "Discharged Against Medical Advise" (DAMA).

Adebajo [38] summarized the causes of structural collapses and failures in Nigeria from a series of building collapse investigations by the Nigerian Institute of Structural Engineers as:

Non adherence to the approval regulations; Absence of the involvement of a professional structural engineer in one or more of the stages of the project execution; Incompetent and low quality workmanship; Use of poor quality materials; Lack of soil investigation and improper interpretation of site conditions; Lack of professional site supervision; Lack of knowledge of the guiding principles concerning construction of the proposed development; Greed and the desires to maximize profit; Excessively rushed construction; Poor or inadequate form and false work; Corner cutting by the client or the contractor; Construction by all-comers due to the perception of engineering projects as an easy access window to make quick money; Unethical dealings between project promoters and the relevant planning authorities.

The above points can be subsumed in lack of professional standards in the building process. Unexpected rivalry and unreasonable comparison among allied building professionals is another dimension to the problem. The Registered/Chattered Architect is the "Arch-builder" simply meaning Master Builder who has the overall concept of the building as a piece of "dreamed" architectural piece and others are supposed to add inputs to the architect's established framework. Toiling with this Prime Consultant status of the architect is a signal to future calamities. Quackery, poor design, wrong estimation of the building loads and soil bearing capacity, natural forces like earthquakes, tremors, landslide, flooding, and high-velocity winds use of sub-standard materials, poor quality control and lack of professional supervision are co-indicators of collapse of buildings. Superficially strong buildings collapse at the impact of flooding and storms.

\section{CONSEQUENCES OF BUILDING COLLAPSE IN NIGERIA}

The catastrophic outcomes of collapse of buildings are awesome on individuals, families, professions of all kinds including medicine, society and the government. The loss of lives and properties, stress, trauma and shocks that accrues to the owners and occupants of collapsed buildings are unimaginable. According to Ede (2010) collapse of buildings increases mortality rate and runs against the United Nations MDGs programmes aimed at reducing the 
mortality rate and improving safety and life expectancy of the world population. Adedeji (2013) discovered that 280 people were killed by collapsed buildings while the total casualty was 453 in few reported cases in selected cities in Nigeria between 1990 and 2009.

In addition to being direct victims of collapse of buildings, medical practitioners are often at the centre of activities in post-collapse events. Accident and Emergency Sections, Mortuaries, Wards, Laboratories, Intensive-care Units, Eye, Nose and Tongue (ENT) Units, and Psychiatric Sections of healthcare facilities are often the destinations of casualties of collapsed buildings. This increases the workload of medical professionals on regular duties, call duties and emergencies. In extreme cases, healthcare spaces designed for normal and regular activities are overcrowded making them unserviceable for designed purposes. The unquantifiable amount of financial and time resources expended by all coupled with the grief of loss of parts of the body or complete death of loved ones who may be breadwinners make the incidences of collapse of buildings worrisome.

The technological, spatial and financial challenges of demolishing the remnants of collapsed buildings and clearing of rubbles place a high demand on the owner and near-neighbours of collapsed buildings. These include the movement and operation of heavy de-construction equipments in built-up areas and their negative vibration effects on adjacent structures. The displacement of survivors from their regular dwellings or work environments leads to psychological and physical overcrowding in the places where they are temporarily accommodated.

Figure 2 to 7 show the sorrow that engulfs the bereaved relations of those killed in incidences of collapse of buildings whose positions are made vacant in the family, social and religious organisations, and places of work suggests the need for all stakeholders to stop paying lip service to the problem.

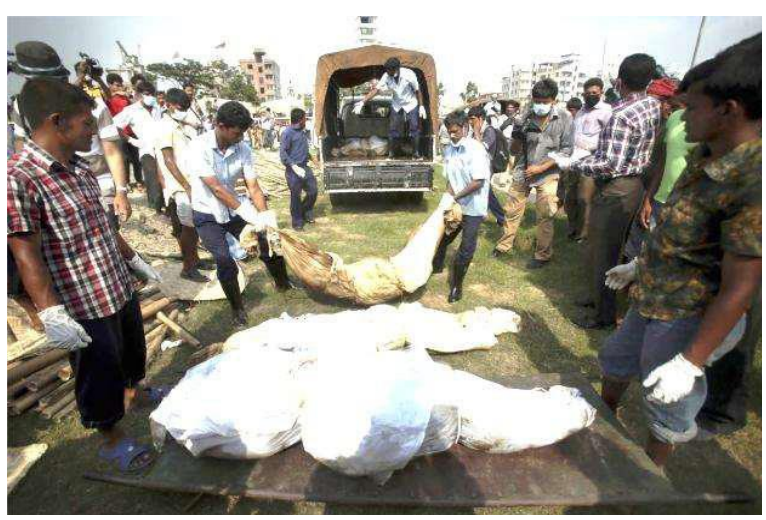

Figure 2. Dead bodies from the site of the collapsed eightstorey Rana Plaza garment factory in Savar, near Dhaka in Bangladesh. (Source: Google images).

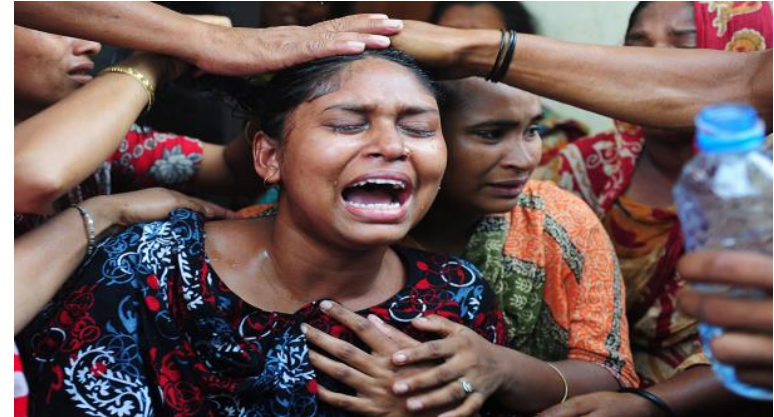

Figure 3. A relative reacts after identifying the body of a loved one killed building collapse in Savar. (Source: Munir Zaman/Getty Images)

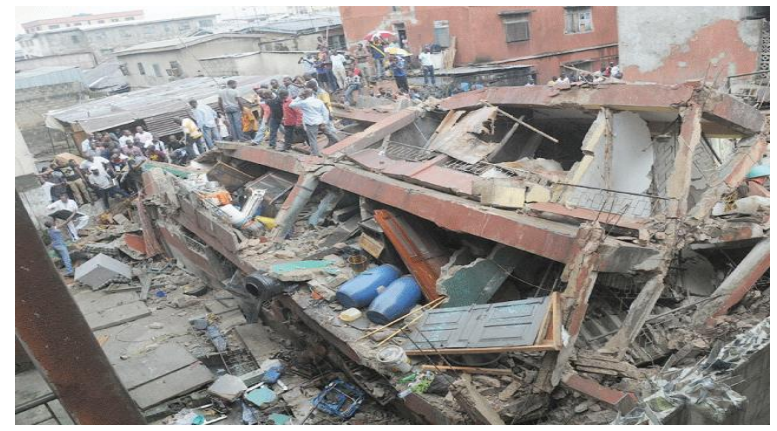

Figure 4. Building collapse in Lagos. (Source: http://dailypost.com.ng/wp-content/uploads/2013/07/Lagos_collapsed_ building.if)

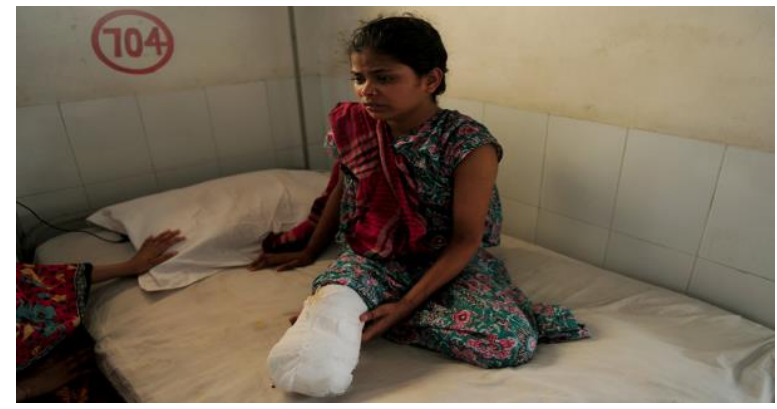

Fugure 5. A young garment worker who was rescued from a building that collapsed sits on a hospital bed with an amputated leg. (Source: Munir Zaman/Getty Images)

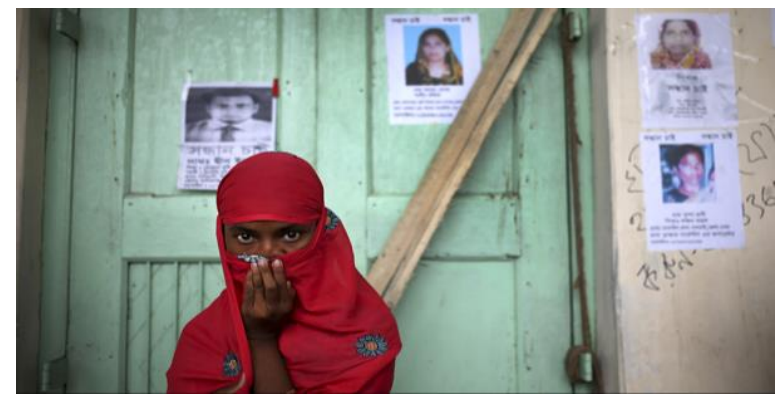

Figure 6. A woman covers her nose at a morgue where bodies recovered from the garment factory collapse are kept for identification. (Source: http://www.washingtonpost.com/ blogs/worldviews/wp/2013/05/10/10-heartbreaking-photosfrom-the-building-collapse-in-bangladesh/) 


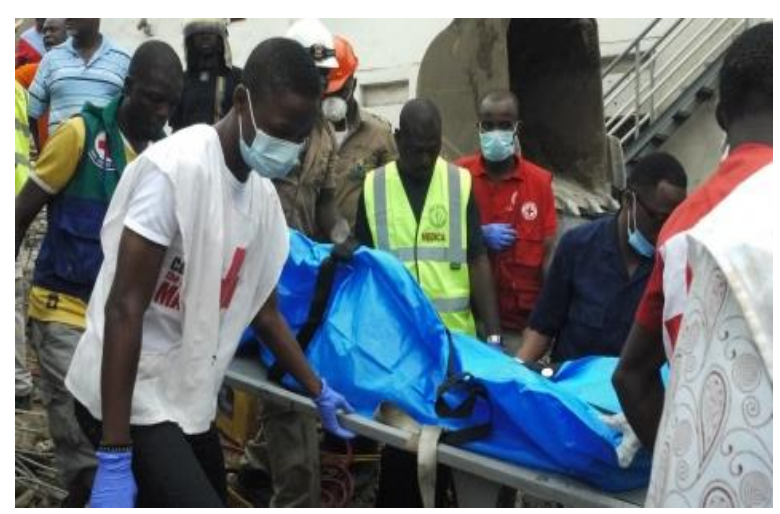

Fugure 7. Four persons, including a 15 -year-old hawker identified only as Sukurah, lost their lives after a two-storey building under construction, collapsed in Surulere, Lagos State. (Source: http://urbanpostng.com/news/photos-4-killed -in-lagos-building-collapse/)

\section{STRATEGIC PRESCRIPTIONS FOR MANAGEMENT OF BUILDING COLLAPSE IN NIGERIA}

Environmental management identifies three strategies for coping with the problem of collapse of buildings. These include prevention, preparedness and mitigation (Adedeji and Adeboyejo, 2011) with risk factors in ascending order across the life-cycle of buildings from cradle to "death." At various scales and depending on peculiar situations, all the three are relevant to cases of vulnerability of individuals, families, governmental agencies and the entire society to collapse of buildings.

Prevention, though hard and almost impossible to achieve in natural hazards, is the best method of disaster management compared to mitigation and preparedness. It is defined as the "activities to provide outright avoidance of the adverse impact of hazards and means to minimize related environmental, technological and biological disasters" (ISDR, 2002). This is usually attainable at the pre-contract stage and post-contract stages of buildings. It is the terrain of responsibilities of built environment professionals, building owners, builders and contractors and governmental agencies on the built environment. It involves ethical professional procedures during building design and specification and actual construction. Here, the enforcement of the various building and planning legal instruments like the National Building Code (2006) is germane. However, at this management level, aside from being involved in decision making of design programme formulation as a client or client's representative, the medical professionals have no relevant roles to play.

Furthermore, preparedness is defined as "activities and measures taken in advance to ensure effective response to the impact of hazards, including the issuance of timely and effective early warnings and the temporary evacuation of people and property from threatened locations" (ISDR, 2002; IFRCRCS/ Provention Consortium, 2007). This is essentially the domain of emergency management agencies. The National Emergency Management Agency (NEMA) is prominent in this regard. The agency was born out of National Emergency Relief Agency (NERA) via Act 12 as amended by Act 50 of 1999 with the mandate to:

a. Formulate policy on all activities relating to disaster management in Nigeria and co-ordinate the plans and programmes for efficient and effective response to disaster at national level;

b. Co-ordinate and promote research activities relating to disaster management at the national level;

c. Monitor the state of preparedness of all organizations or agencies which may contribute to disaster management;

d. Collate data from relevant agencies so as to enhance forecasting, planning and field operation of disaster management;

e. Educate and inform the public on disaster prevention and control measure;

f. Coordinate and facilitate the provision of necessary resources for search and rescue and other types of disaster curtailment activities in response to distress call.

In conjunction with state governments, it is the responsibility of NEMA to set up state activities office as State Emergency Management Agency (SEMA) while SEMA is responsible for setting up of Local Emergency Management Agency (LEMA) in the respective local governments of the state. In case of incidence of collapse of buildings, NEMA is supposed to coordinate, support and enhance the activities of the Red Cross Society to ensure successful rescue operation. The medical profession is very crucial to these activities and should treat cases of victims of collapsed buildings as emergently as possible. The recovery and wellness of the victims is an index of the effective treatment and timely intervention of medical attention. This places a high demand and challenge on the medical practitioners working in the healthcare facilities where victims of collapsed buildings are hospitalised.

Mitigation is any "structural (physical) or nonstructural (e.g. land use planning, public education) measure undertaken to minimize the adverse impact of potential natural hazard events" (ISDR, 2002). In relation to collapse of buildings, mitigation is the 
purview of governmental development control agencies. There is need for the appointment of qualified and expert building professionals including architects, structural engineers and building services engineers in these agencies and by building clients, both public and private, in all the stages of building development-design, construction and post-occupancy maintenance, the importance of the statutory implementation of all physical development planning regulations, acts, bye-laws and codes in the processing of building permit, construction supervision and prosecution of culprits cannot be over-emphasized.

\section{PROGNOSIS OF BUILDING COLLAPSE IN NIGERIA}

The predicament of humans through collapse of buildings in the past and present has been implicated upon many causal agents. A closer look at the dichotomy of the classification of the causatives to human and natural forces suggests that the human factor is overriding. The collapse of Tower of Babel was premised upon human corruption which has increased over the generations and consequently the spate of building collapse has increased from decade to decade even in the so-called advanced nations. Will it not be a form of "insanity" not to change method and expect different result? Unfortunately, the canker called corruption has been "modernized" and branded "Nigerian factor" in a country of religious millions of stakeholders in the built environment. Ogunsote and Ogunsote [2] summarized this as "pecuniary facilitators" of collapse of buildings called greed. They expanded it to mean:

Cost savings by not using qualified and certified consultants and workers; Use of cheaper but structurally inferior materials; Use of insufficient quantities of, or omission of key structural elements; Building on cheaper but unstable soil without necessary reinforcement; Cost savings by neglecting essential tests; Cost savings through elimination or reduction of structural redundancy, and considering such as unnecessary luxury; Cost savings through reduction or elimination of regular maintenance of critical structural elements; Ignoring signs and warnings of imminent structural failure because of the cost implications of repairs.

Atume (2012) [50] further expanded the "Nigerian factor" thesis by listing the forms in which it appears in the building industry and they include the following:
Corruption; Lack of supervision; Bad governance; Misuse and abuse of authority by those in authority especially some of the professionals; Insufficient quality control and standards; Lack of sanctions against erring professionals and landlords; Illegal conversion of buildings which often lead to structural deficiencies; Non adherence to approval regulations; Lack of soil investigation and improper interpretation of site conditions; Negligence; Unethical dealings between project promoters and the relevant Planning Authorities; Non-involvement of registered professionals in one or more stages of the project; Poor and bad construction practices; Incompetent and low quality workmanship; Greed; Corner cutting by client or the contractor; Hasty construction; Use of poor quality materials/poor or inadequate form and false work; Construction by all-comers due to the perception of Engineering as an easy access window to make quick money.

The continual existence and more unfortunately the increase of these conditions in the Nigerian system of handling building procurement is an indication that the future of collapse of buildings in the country may be worse than the past or present. The "gains" from the facilitation of collapse of buildings cannot be compared with the loss. It is therefore wickedness, lack of passion, injustice, heartlessness and mischievousness of the highest order to continue in these inhuman acts.

\section{RECOMMENDATIONS AND CONCLUSION}

This paper has given a general overview of collapse of buildings and its medico-spatial implications. In view of the far-reaching outcomes of its occurrences, it might be pardonable rhetoric to reemphasize the roles medical and dental practitioners can play in abating it:

$>$ Ensuring adequate and continual vigilance on all elements of personal and official residences and healthcare buildings to detect the earliest and most unnoticeable symptoms of decay, failure, or threat to safety;

$>$ Co-opting medical and dental professionals as major stakeholders in the formulation, review and enforcement of National Building Code for design, construction and occupancy of buildings;

> Undertaking Retainer Services, Mobile Clinic and Ambulance Services for standard construction companies as preparedness strategy; 
Arranging for provision of first-aid services on construction sites and providing Retainer Services to families;

> Facilitating timely and appropriate intervention of raising alarms, remedying defective elements of the building, outright vacation of the building, and reporting to appropriate authorities;

$>$ Avoiding all forms of "corner-cutting" and avoid greed as a "monster" at all stages of building procurements from design to construction, occupation as clients or clients' representatives;

$>$ Appointing professionally qualified registered Architect as Prime Consultants in all matters of building;

> Conducting regular and systematic "building check-up" much similar to medical check-up through post-occupancy evaluations and building auditing to discover what works well and what does not to enhance good maintenance culture.

$>$ Treating cases of survivors of collapsed buildings as emergent as possible.

Holistic and strict adherence to these recommendations is a sure way of achieving safe, serviceable and aesthetically pleasing built environment in Nigeria through the much-cherished services of medical professionals.

\section{REFERENCES}

Adebajo, K. (2005). "A position paper by the Nigerian Institution of Structural Engineers (NIStructE), a division of the Nigerian Society of Engineers (NSE) on Recent Structural Collapses in Nigeria and the prevention of future incidences" downloaded from http://www.nistructe.org/publications_details.php?site_id=3\&re solut... on 31/03/2009.

Adedeji, J. A. (2013). Environmental Disasters and Management - Case Study of Building

Collapse in Nigeria. International Journal of Construction Engineering and Management, 2(3), $39-45$.

Adedeji, J. A. and Adeboyejo, T. A. (2011) Environmental Hazards, Disasters and Pollution:

Global, African and Nigerian Patterns. Alina Covali (Ed.) Saarbrücken, Germany: LAMBERT Academic Publishing.

Akindoyeni, A. (2012). Effective Disaster Management at the Sites of Collapsed Buildings. Curbing the Incidences of Building Collapse in Nigeria: Proceedings of National Technical Workshop on Building Collapse in Nigeria, Abuja, 15-16 May 2012, p.147-163.
Akinwale, A. A. (2010). The Menace of Inadequate Infrastructure in Nigeria. African Journal of Science, Technology, Innovation and Development, 2(3), 207-228.

Atume, F. (2012). Causative Factors of Building Collapses in Nigeria. Curbing the Incidences of Building Collapse in Nigeria: Proceedings of National Technical Workshop on Building Collapse in Nigeria, Abuja, 15-16 May 2012, p. 78-95.

Bull-kamanga, L., Diagne, K., Lavell, A., Leon, E., Lerise, F., MacGregor, H., Maskrey, A., Meshack, M., Pelling, M., Reid, H., Satterthwaite, D., Songsore, J., Westgate, K.., and Titamber, A. (2003). From Everyday Hazards to Disasters: The Accumulation of Risk in Urban Areas. Environment \&Urbanization. 15(1), April.

Carmona M, Heath Tim, Oc, T, Tiesdell, S (2003). Public places-urban spaces. The dimensions of urban design. Oxford: Architectural Press

Chinwokwu, G. (2000). "The Role of Professionals in Averting Building Collapse" Proceedings of a 2Day Seminar of the Nigerian Institute of Building (Lagos State Chapter) on Building Collapse, Causes, Prevention and Remedies, Lagos Airport Hotel, Ikeja 3 de Bono, E. (1977). Lateral Thinking, Harmondsworth: Penguin.

Ede, A. N. (2010). Building Collapse In Nigeria: The Trend Of Casualties In The Last Decade (2000 2010) International Journal of Civil \& Environmental Engineering, 10(6),32-42

Fadamiro, J. A. and Adedeji, J. A. (2012). Cultural Morphology of Cityscapes: A Semiotic Analysis of Osogbo, Nigeria. Alina Covali (Ed.) Germany: LAMBERT Academic Publishing.

Fakere, A. A., Fadairo, G. \& Fakere, R. A. (2012). Assessment of Building Collapse in Nigeria: A Case of Naval Building, Abuja, Nigeria International Journal of Engineering and Technology, 2(4), 584-591.

Golu, T. (2008). Nigeria: Building Collapse-Any Remedies? Available at http://allafrica.com/stories/printable/20080810684.html Google images

Gordon, W. J. J. (1961). Synectics: the Development of Creative Capacity, New York: Harper Row.

http://dailypost.com.ng/wp-content/uploads/2013/07/ Lagos_collapsed_building.if

http://www.washingtonpost.com/blogs/worldviews/w $\mathrm{p} / 2013 / 05 / 10 / 10$-heartbreaking-photos-from-thebuilding-collapse-in-bangladesh/

http://urbanpostng.com/news/photos-4-killed-in-lagosbuilding-collapse/)

Ibrahim, R. B. (2013) Monumental effects of building collapse in Nigerian cities: The case of Lagos Island, Nigeria. Basic Research Journal of Engineering Innovation Vol. 1(2), 26-31. 
IFRCRCS, International Federation of Red Cross and Red Crescent Societies/the Provention Consortium (2007) Tools for Mainstreaming Disaster Risk Reduction: Vulnerability and Capacity Analysis accessed from www.proventionconsortium.org.

Ike, A. C. (2012). Case Histories of Building Collapses in Nigeria. Curbing the Incidences of Building Collapse in Nigeria: Proceedings of National Technical Workshop on Building Collapse in Nigeria, Abuja, 15-16 May 2012, p. 55-77.

Ikpo, J. I. (2005).The Builder's Liability Beyond The Defects Liability. Civil Engineering Dimension, 7(1), 16-21.

ISDR, International Strategy for Disaster Reduction (2002) Terminology of Disaster Risk Reduction downloaded on 28/03/09 from file://E:/ISDR\% 20\% Terminology.htm.

Jacobs, J. (1961, 1984 edition), The Death and Life of Great American Cities: The failure of modern town planning. Pereqrine Books, London.

Munir Zaman/Getty Images.

Nwachukwu, C. C. and Emoh, F. I. (2011). Building Construction Project Management Success as a Critical Issue in Real Estate Development and Investment, American Journal of Social and Management Sciences, 2(1), 56-75.

Obiechina, N. (2005). How Stakeholders can conquer the monster of building collapse. The Guardian, Monday, August 22, 2005, p. 43, 44.

Ogunsote, O. O. and Ogunsote, B. P. (2013). The Menace of Building Collapse in NigeriaPecuniary Facilitators and Human Costs of
Catastrophic Structural Failure. A Seminar paper presented at School of Environmental Technology, FUTA, Nigeria.

Open History Society (2013). Tower of BabelDonald Trump. Retrieved from http://www. openhistorysociety.org/wp-content/uploads/2012/ 06/Tower-of-Babel-Donald-Trump1.jpg.

Olabulo, O. (2012). Collapsed building kills medical doctor, sister, aged mother in Lagos. In Nigerian Tribune, Thursday, 22 November 2012.

Rapoport, A. (1979). Cultural Origins of Architecture, In Snyder, J. C., Catanese, A. J.(eds.).

Introduction to Architecture. New York: McGrawHill, Inc. p. 3-20.

Leong, D. (2010). "Street Signs: Toward a Missional Theology of Urban Cultural Engagement." Fuller Theological Seminary, School of Intercultural Studies. Doctor of Philosophy, p. 343.

Saunders, P. (2001). Urban Ecology in Handbook of Urban Studies, Paddison, S. (ed.) London: SAGE Publications Ltd.

Savage, M. and Warde, A. (1993). Urban Sociology, Capitalism and Modernity. London: Macmillan.

Wikipedia (2013a). List of structural failures and collapses. Available at en.wikipedia.org/wiki/ List_of_structural_failures_and_collapses.

Wikipedia (2013b). Tower of Babel. Available at http://en.wikipedia.org/wiki/Tower_of_Babel.

Windapo, O. A. and Rotimi, J. O. (2012). Contemporary Issues in Building Collapse and Its Implications for Sustainable Development Buildings 2012, 2:283-299. 